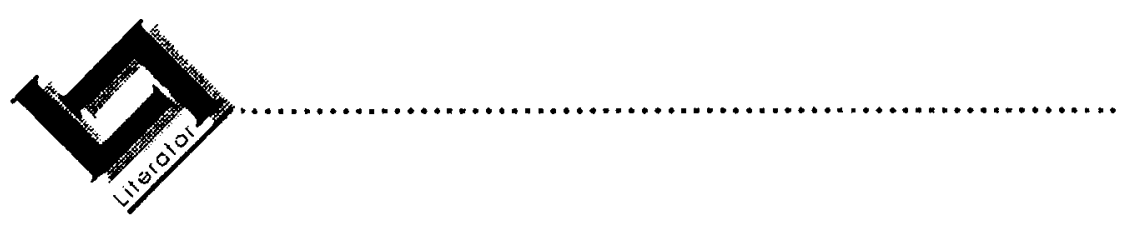

\title{
Karakters vir jeugdige lesers
}

\author{
S.F. (Franci) Greyling \& Hans du Plessis \\ ATKV-skryfskool \\ Potchefstroomse Universiteit vir $\mathrm{CHO}$ \\ POTCHE'FSTROOM \\ E-pos: greyling@intekom.co.za \\ hgwdp@puknet.puk.ac.za
}

\section{Abstract \\ Characters for young readers}

In discussions on the nature of children and youth literature, various aspects occur repeatedly. The presumption that these aspects are a/so factors that exert a meaningful influence on the characters in the genre is largely confirmed by research. Based on developmental characteristics, 11-14 year-olds are identifiable as a group with a unique profile. From this it follows that a relationship between the reader profile en genre conventions can be indicated and that it can be applied specifically to character as an element of the narrative. Characteristic genres and genre conventions establish a framework of expectations within the reader, which co-determines the selection, creation and portrayal of characters. The social cognitive development of the young reader appears to be of special importance in character portrayal. Reader identification with characters largely contributes to reader involvement and to the pleasure a young reader derives from the reading of stories. As a result of the educational situatedness of the young reader, ideology plays an important role in literature for the young. Successful characters have always been regarded as important in ensuring the success of a story. Through selection and the equipping of characters, and by means of portrayal, the writer can work towards this aim.

\section{Inleiding}

Stories gaan oor karakters - oor mense. Stories word deur mense gelees - waarvan sommige mense ouer, en ander jonger; party ervare en ander minder ervare is; mense wie se belangstellings, behoeftes en leesmotivering verskil. Kan 'n skrywer doelmatige en doeltreffende karakters vir'n bepaalde lesersgroep skep? Is daar aspekte wat die 
skrywer van kinder- en jeugverhale in besonder in ag moet neem wanneer oor karakters in die verhaal besluit word? Is dit van belang hoe karakters geskep en in 'n teks voorgestel word?

Die bewering dat verhale nie spesifiek vir sekere lesersbehoeftes, of vir bepaalde ouderdomme geskryf word nie, word dikwels gemaak (Lohann, 1972:11-12). Ander is weer van mening dat die implisiete leser reeds teenwoordig is tydens die beplanningstadium van die manuskrip (Steenberg, 1986:86). Die skrywer bou immers die leser van sy keuse by implikasie in die teks in deur die keuse van karakters, handeling, woordgebruik, sinsbou en verteltegnieke (Steenberg, 1991:38). Hierdie keuse kan 'n bewustelike en weldeurdagte besluit wees, of die resultaat van keuses wat tydens die skryfproses gemaak is

In die ondersoek na die aard, definisie en grensafbakening van kinderen jeugliteratuur kom die volgende aspekte telkens ter sprake: kinder- en jeugliteratuur is gerig op 'n bepaalde lesersgroep met eiesoortige kenmerke, vermoëns en behoeftes. As gevolg van die besondere leser, speel die werklikheidsbeskouing 'n belangrike rol ten opsigte van die aard, evaluering en aanwending van die genre. Hierbenewens word in die gesprek rondom die literatuurvorm dikwels gewag gemaak van die verskillende en eiesoortige subgenres asook die beleweniswêreld van die jeugdige. Ten opsigte van karakters word dikwels verwys na die aantoonbare verband tussen die ouderdom, leeftydfase of eienskappe van die teikengroep en sentrale karakters. Die identifisering met karakters is telkens ter sprake. Daar word vermoed dat dié aspekte die grootste invloed op die onderskeie struktuurelemente uitoefen. Hieruit volg die veronderstelling dat indien dié aspekte met die teikengroep en skeppingselement karakter in verband gebring kan word, dit die essensie van karakterkeuse, -skep en -voorstelling in verhale vir jeugdige lesers sal omvat.

Die implisiete leser van 'n teks kan algemeen wees (lesers van speurverhale) of nader gespesifiseer word (tienermeisies wat van liefdesverhale hou). Die ouderdomsgroep 11-14 jaar kan as 'n sodanige lesersgroepering dien. Die bedoeling met hierdie ouderdomsafbakening is nie om lesers in hokkies en vakkies te forseer nie, maar slegs om as fokuspunt te dien om die leser, genre en skeppingselemente van nader te beskou.

Insigte vanuit verskeie dissiplines (leserkunde, literêre teorie, skryfkuns, psigologie en opvoedkunde) bevestig dat die lesersgroep van 11-14 jaar 'n kenmerkende profiel vertoon, dat karakteristieke genrekonvensies aangetoon kan word, en dat daar faktore is wat besonder tersaaklik is vir die keuse, skep en voorstelling van karakters in verhale vir dié 
teikengroep (Greyling, 1999:388). Die skrywer kan hierdie beginsels na gelang van behoefte aanpas - hetsy om 'n breër lesersgroep te bereik, of om ' $n$ bepaalde verhaaltipe vir 'n afgebakende teikengroep te skep.

\section{Die teikenleser}

Wat maak die 11-14-jarige uniek? Waarom is dit waardevol dat die skrywer insig in dié lewensfase het, en watter implikasies kan dit inhou vir die keuse, skep en voorstelling van karakters in verhale vir dié teikengroep?

'n Mens beweeg deur verskeie lewensfases. Tussen kindwees en volwassenheid word die adolessente-fase onderskei. Die leeftydsegment wat in hierdie artikel ter sprake is, is die vroeë adolessensie wat geassosieer word met die eerste fase van abstrak-kognitiewe denke. Dié ouderdomsgroep bevind hulle gewoonlik in die vyfde tot agtste skooljare. Ten spyte van onderlinge individuele verskille, kan algemene ontwikkelingstendense aangetoon word, byvoorbeeld ten opsigte van kognitiewe, sosiale, morele, affektiewe en liggaamlike ontwikkeling. Kognitiewe en sosiaal-kognitiewe denkontwikkeling dien hier as vertrekpunt

Ten opsigte van die kognitiewe (denk-)ontwikkeling bevind die 11-14jarige hom- of haarself, aldus Piaget, in die aanvangsfase van abstrakoperasionele denke. In die konkreet-operasionele denkfase wat dié stadium voorafgaan, is die kind van konkrete denke afhanklik en neig om probleme in isolasie te hanteer. Hierteenoor het die formeel-operasionele denker 'n goed ontwikkelde begrip van oorsaak en gevolg en is hy of sy in staat om teorieë en hipoteses in die oplossing van probleme te gebruik, verskeie intellektuele denkvaardighede gelyktydig te benut, en wetenskaplik te redeneer. Die ontwikkeling van abstrakte denke bring ook mee dat die jeugdige tot introspeksie in staat is en oor eie denke en gevoelens kan dink en dit kan analiseer (Wadsworth, 1989:116).

Nóú verwant aan kognitiewe ontwikkeling is die sosiaal-kognitiewe begrip - die individu se konsep van homself en van ander. Waar 'n jonger kind homself en ander in terme van fisiese voorkoms, besittings en handeling beskryf, verwerf die adolessent toenemend die vermoë om psigologiese dimensies in homself en ander te herken en as vergelykingsbasis te gebruik (Hill \& Palmquist, 1978:6; Barenboim, 1981:33). Die jeugdige begin insien dat ander se visie en siening van syne verskil, en kan hom- of haarself in ' $n$ ander se posisie indink; hy of sy kan afleidings maak oor ander se gedrag, en besef dat uiterlike gedrag en innerlike motivering nie noodwendig ooreenkom nie (Shaffer, 1988:176180). Gepaardgaande hiermee begin die jeugdige 'n eie teorie oor mense se persoonlikhede vorm. Bogenoemde is afhanklik van sosiale 
ervaring en die toenemende vermoë tot abstrakte redenering (Shaffer, 1988:181). (Oor die algemeen verwerf dogters vroeër die vermoë om afleidings en gevolgtrekkings oor sosiale gedrag te maak. Seuns bly langer aan die fisiese, konkrete en uiterlike gebeure gebonde.)

Verskeie studies toon 'n verband aan tussen die kognitiewe ontwikkelingsvlak van die individu, sy konsep van, en die wyse waarop verhale verstaan word, asook 'n verband tussen sosiale begrip en die begrip van verhaalkarakters. Kinders se vermoë om afleidings oor karakters se motivering, gevoelens en denke te maak, ontwikkel op soortgelyke wyse as sosiaal-kognitiewe begrip. Dit bring mee dat lesers nie in staat is om tot afleidings oor karakters (optrede, motivering, aard) te kom indien dié interpersoonlike vaardigheid nog nie verwerf is nie.

Die begrip van ' $n$ teks en karakters is afhanklik van lewens- en leeservaring. Alhoewel alle tekste van 'n leser verwag om afleidings te maak, verskil die aard van die verwagting heelwat tussen tekste. Waar sommige tekste 'n geslote struktuur en relatief min oop plekke het, en nie van die leser veel betrokkenheid verwag nie, verg ander dat die leser deur aktiewe deelname en insig tot betekenisgewing moet bydra. In 'n dialoogsituasie moet die leser byvoorbeeld spraakhandeling begryp, sosiale en kulturele gebruike verstaan, en met literêre of genrekonvensie vertroud wees (Beach, 1985:112). 'n Jong leser wat nog nie oor die nodige kennis, lewens- of leeservaring beskik nie, is nie in staat om tot die verwagte gevolgtrekkings te kan kom nie. Dit beïnvloed nie slegs die begrip vir karakters en karakteroptrede nie, maar raak ook die belewenis van die verhaal (leeservaring). 'n Eenvoudige voorbeeld: wanneer 'n karakter dae op ' $n$ kalender afmerk, sal die ouer en ervare leser kan begryp dat dit met 'n moontlike swangerskap verband kan hou. Die jong leser wat nie oor die nodige agtergrond beskik nie, sal waarskynlik nie dié afleidings kan maak en die gepaardgaande spanning of opwinding (na gelang van die karakter se situasie) beleef nie.

Beach en Wendler (1987:293) bevind dat, ten opsigte van die belewing en persepsie van karakters se optrede, perspektief en doelwitte, jonger lesers (14 jaar) beduidenisvol meer konsentreer op karakters se fisiese optrede, gevoelens en korttermyndoelwitte. Ouer respondente (kollegestudente) fokus meer op karakters se sosiale en psigologiese stand, hul oortuigings en langtermyndoelwitte. Handeling en gebeure is regstreeks waarneembaar, en dus meer opvallend en konkreet. Hierteenoor is innerlike gesteldheid nie regstreeks waarneembaar nie, minder opvallend, en dus abstrakter. Die vermoë om psigologiese afleidings te maak, en langtermyndoelwitte te begryp, verg dus 'n hoër vlak van kognitiewe en sosiaal-kognitiewe denke. 
Die leser dra egter nie noodwendig sosiale begrip na verhale en karakters oor nie. Verskeie faktore kan dié oordrag beïnvloed, waaronder die motivering, leesstrategie, leesomstandighede, emosionele ingesteldheid en persoonlikheid van die leser. Faktore wat met die teks verband hou, is onder andere die genre, verteltegnieke en die verhouding wat tussen die leser en skrywer opgebou word.

Jeugdiges van dieselfde ouderdom se kognitiewe ontwikkeling, leesvermoë en leesontwikkeling, leesbelangstelling, en lees- en lewenservaring verskil dikwels opmerklik. In dieselfde klas kan leerders wees wat twee jaar bo, en ander twee jaar onder die gemiddelde leesontwikkeling funksioneer - sodat die leesouderdom in die betrokke klas met soveel as vier jaar kan verskil (Vos \& Meijer, 1985:132). Dit verklaar waarom een kind groot plesier uit die wedervaringe van stereotiepe reeksboekkarakters kan put, en 'n ander dieselfde boek as vlak en kinderagtig beskou.

Dié lesersverskeidenheid bring mee dat daar nie net een benadering ten opsigte van karakters is wat vir alle lesers geld nie. Waar die een leser 'n eenvoudige, duidelik gedefinieerde karakter verkies, is ' $n$ ander in staat om karakternuanses raak te sien en te waardeer. Die skrywer kan wel, met die beoogde leser en gewenste leesresultaat in gedagte, die hantering van karakters aanpas. Kennis van die kenmerkende eienskappe en vaardighede waaroor 'n leser beskik, kan dus vir die skrywer van waarde wees wanneer besluite oor die genre, karakter en skryftegnieke geneem word.

\section{Identifisering met karakters}

Die betrokkenheid van ' $n$ leser by ' $n$ verhaal word allerweë as belangrik beskou - in kinder- en jeugverhale is dit een van die primêre eise wat gestel word. Navorsing toon dat die teikengroep in besonder met karakters identifiseer en dat dit 'n belangrike rede is waarom verhale gelees en geniet word (Whitehead et al., 1978:208; Applebee, 1978: 124).

Die aard en omvang van dié betrokkenheid kan verskillende vorme aanneem. Jauss (1977:220) onderskei tussen assosiatiewe, bewonderende, simpatieke, katarsiese en ironiese identifisering wat 'n aanduiding van die aard van die identifisering gee. Die afstand tussen leser en karakter kan ook wissel. Die leser kan byvoorbeeld die avonture as onsigbare karakter meemaak, hom- of haarself in die plek van karakters stel, en die self in die karakter projekteer (Protherough, 1983:21-22). 
Die ontwikkelingsfase waarin 'n individu hom- of haarself bevind, is ook ten opsigte van lesersbetrokkenheid opmerklik. Waar jong lesers eerder met uiterlike karakterhandeling identifiseer, is ouer lesers ook tot empatiese en gevoelsmatige identifisering in staat. Kinders van 11-12 neig om hulself in ' $n$ karakter en situasie te projekteer; hierteenoor neem ouer respondente $(14+)$ tot 'n groter mate die rol van 'n verwyderde toeskouer en onbetrokke evauleerder in (Protherough, 1983:21). Hierdie bevindinge beteken nie dat ' $n$ ouer leser nie meer tot projeksie of identifisering in staat is nie, maar wel dat die leser na gelang van die behoefte, verskeie leeswyses kan gebruik. Seuns sal waarskynlik langer met die uiterlike handeling identifiseer, terwyl meisies vroeër tot empatiese identifisering geneig is. Verskille in leesvoorkeure kan onder andere hierdeur verklaar word.

Die leesstyl van 'n leser bepaal ook die aard van lesersbetrokkenheid. Die meeste lesers hanteer teks as 'n uitbreiding van die werklikheid en beskou karakters as werklike mense. Die karakter se ervaring word derhalwe as soortgelyk aan dié van die leser herken en soos die leser se eie ervaringe verstaan (Dillon, 1982:80-81). Dié leesstyl wat hom veral tot identifisering leen, word oorwegend deur 11-14-jariges gebruik (Applebee, 1978:132-133).

Die skrywer kan op verskeie wyses die estetiese afstand tussen leser en verhaal beïnvloed en die moontlikhede van lesersidentifisering met karakters rig.

Die aard van die teks beïnvloed reeds die afstand tussen die leser en die karakter. Indien die verhaal van literêre tegnieke gebruik maak wat vir die leser vreemd is, word afstand geskep, en vind identifisering met die karakter nie so maklik plaas as wanneer die leser met die genre en konvensies vertroud is nie. Jong lesers gee dan ook voorkeur aan 'n ortodokse vertelwyse bó psigologies- en tegnies-eksperimentele skryfwerk. Die tipe verhouding wat tussen die teks en die implisiete leser opgebou word, is genre-spesifiek (Tucker, 1981:37; Knight, 1997:127). 'n Speurverhaal vereis eerder denkvernuf en ontrafeling van ' $n$ misdaad of geheim as wat dit om emosionele betrokkenheid by die karakter gaan. Die sukses van 'n riller steun hierteenoor, vir die opbou van spanning, sterk op die identifisering van die leser met die slagoffer (Tucker, 1981:37).

Ooreenkomste tussen die leser en die karakter kan tot identifisering bydra. Jong lesers verkies dikwels verhale waarin die sentrale karakter van die ooreenkomstige geslag is. Hierdie voorkeur dui reeds op 'n gewilligheid om met die betrokke karakter te identifiseer. Jong lesers lees graag oor, en identifiseer met karakters wat soortgelyke eienskappe 
en ervaringe deel. Benewens geslag is ouderdom, etnisiteit, en leef- en beleweniswêreld aspekte wat die karakter vir die leser bekender maak. Voorafgaande is nie per se bewustelik nie. Alhoewel ooreenkoms tussen leser en karakter identifisering kan vergemaklik, sluit onderlinge verskille dit nie uit nie. Die skryftegnieke wat die skrywer gebruik, kan die identifiseringsmoontlikhede verder beïnvloed, asook die aard daarvan bepaal.

Die wyse van voorstelling, die gekose vertelstrategie, die aard van die gesigspunt en verteltegnieke speel 'n belangrike rol ten opsigte van identifiseringsmoontlikhede. 'n Vertelstrategie wat 'n vertrouensverhouding met die leser skep en hom of haar in die skoene van 'n enkel karakter-fokalisator plaas, dwing die leser om met dié karakter te vereenselwig. Die eienskappe waarmee 'n karakter toegerus word en die rol wat die karakter in die storie vertolk, dra verder daartoe by of 'n leser met die karakter wil identifiseer. 'n Handelende hoofkarakter met positiewe en altruïstiese eienskappe is byvoorbeeld 'n aantrekliker karakter om mee te identifiseer as 'n passiewe, negatiewe of selfsugtige karakter.

Die verhaalstruktuur en rol van die karakter in die gebeure is van groot belang. In 'n verhaal waar patrone en karakterdoelwitte duidelik en herkenbaar is, kan die jong leser hom- of haarself maklik met 'n volwasse karakter vereenselwig. Topverkopers maak volgens Tucker (1981:16) in 'n hoë mate gebruik van patrone en strukture wat by die behoeftes van 'n wye verskeidenheid lesers - insluitende kinders aansluit:

(B)est-selling authors can only succeed if they manage first to win and then to hold the interest of a great many diverse readers, and one way of doing this has always been to begin with very basic plots or situations that everyone, children included, could normally find it easy to identify with at the immediate level of undemanding personal fantasy Once any reader's sympathy and curiosity have been aroused through coming to believe in the story and caring about its characters, then of course authors can afford to develop a more subtle approach in what they are doing (Tucker, 1981:16).

Die identifisering met 'n karakter dra by tot die belewing van spanning, begrip en leesgenot. 'n Skrywer kan egter, om bepaalde redes, identifisering ontmoedig. Só word negatiewe karakters dikwels met eienskappe toegerus wat tot afkeer aan die kant van die leser lei. Die held se optrede kan deur dié teenstelling gemotiveer word, dit kan die kontras tussen karakters en gesigspunte illustreer, tot spanningsbelewing bydra, of die tema van 'n verhaal versterk. Blatante dis- 
tansiëring van die sentrale karakter slaag egter nie in kinder- en jeugverhale nie.

\section{Genres en genrekonvensies}

Om in sy bedoelings te kan slaag, is dit vir die skrywer nie slegs van belang om 'n goeie voorstelling van die leser te kan maak nie, maar ook om kennis te dra van die konvensies van die betrokke genre (Steenberg, 1992:151). Die skrywer skryf immers vir lesers wat reeds sekere verwagtinge het (Aucamp, 1992:66).

In sommige verhaalsoorte is dié konvensies betreklik vas en verwag die leser dat sekere karakters in die verhaal sal voorkom en voorspelbaar sal optree; in ander figureer die konvensies nie so prominent nie. Ongeag die spesifieke subgenre, is daar kenmerkende vorme wat oor genregrense heen voorkom en karakterkeuse en karaktervoorstelling beïnvloed. Die Bildungsroman is ' $n$ vorm wat, in kombinasie met die aspek van soektog, in verskeie variasies en verhaaltipes gebruik word. Hierbenewens is ' $n$ jeugdige hoofkarakter, die relatiewe afwesigheid van volwassenes en die belangrike rol wat diere vertolk, kenmerkend van die genre.

Twee hoofbenaderingswyses kan in kinder- en jeugverhale onderskei word, naamlik fantasie en werklikheid. Die manier waarop die skrywer dit hanteer, bepaal in 'n hoë mate die wyse waarop die karakters voorgestel word. Die nuwe realisme het sedert die sestigerjare gedomineer en ook die ander subgenres beïnvloed. Die aandrang op realisme, klem op die individu en persoonlike ervaring, en vertelstrategieë soos die eerstepersoonsverteller en personale fokalisasie is alles aspekte wat ' $n$ invloed het op die karakter. Die eise van 'n ronde karakter en karakterontwikkeling wat dikwels aan realisme gestel word, figureer nie so sterk in fantasie nie - karakter hoef hier nie aan realistiese kriteria te voldoen nie, maar moet wel binne die verhaalwerklikheid oortuig (Steenberg, 1987:22).

Die wesenskenmerke van 'n verhaalsoort verskaf reeds ' $n$ aanduiding vanwaar die klem in die verhaal lê en hoe dit die karakter raak. 'n Onderskeid kan byvoorbeeld gemaak word tussen gebeure, karakter, idee en milieuverhale (Card, 1988:48). Die fokus van die verhaal bepaal verder watter aspekte beklemtoon word. Historiese verhale, avontuurverhale, fantasie, reeksverhale, ensovoorts, word elk deur eiesoortige benaderingswyse, vertelstrategie en karakterverskeidenheid gekenmerk.

Lesers toon dikwels sterk voorkeure vir sekere verhaalsoorte. Reeksverhale is 'n gewilde keuse van die jeugdige leser. Die vorm en inhoud 
van dié verhale sluit in 'n hoë mate by die behoeftes van 'n jong leser aan. Die boeke word gewoonlik gekenmerk deur opwindende en uiterlike gebeure wat die leser nie slegs kan volg en verstaan nie, maar ook kan beleef. Die verhaalstruktuur is grootliks geslote as gevolg van die voorspelbaarheid van die gebeure, verhaalintrige en karakters. Die taal en styl is betreklik konvensioneel, wat sodoende die aandag vestig op die gebeure en nie die taalgebruik as sodanig nie. Karakters is gewoonlik herkenbaar en duidelik uitgebeeld. Besware ten opsigte van reeksboeke hou dikwels verband met stereotiepe uitbeelding en die gebrek aan karaktergeskakeerdheid. Reeksverhale bied egter vir die leser die geleentheid om met die karakters te identifiseer op grond van die skryfstyl, die bekendheid van die karakters, die eienskappe waarmee hulle toegerus word, en die leefwêreld wat soortgelyk is as dié van die teikenleser.

Aangesien literatuur steeds verander, en verhaalsoorte mekaar beînvloed, is dit nie moontlik om vir elke subgenre 'n lysie te maak van soorte karakters, hul eienskappe en die manier waarop hulle uitgebeeld word nie. Die skrywer kan egter wel die algemene tendense en konvensies in ag neem wanneer die karakters vir 'n verhaal gekies, toegerus en voorgestel word. Die manier waarop die skrywer dié konvensies deel van sy skryfwerk maak, en by die leser se verwagtinge aansluit, sal bepaal of dié karakter en verhaal slaag al dan nie.

\section{Vertelstrategie, vertelsituasie en vertelinstansie}

Die manier waarop 'n verhaal vertel word, oefen 'n sterk invloed uit op die wyse en moontlikhede van karaktervoorstelling.

Die vroeëre verhouding tussen skrywer en leser, naamlik dié van 'n alwetende en alwyse volwassene wat van bo af vertel en 'n kinderleser sodoende vermaak of opvoed, het in onguns verval. Hierdie vertelstrategie is grootliks vervang met 'n "gelyke" verhouding tussen die implisiete outeur en leser. Die outoritêre verteller wat van buite die verhaal optree, het plek gemaak vir 'n vertelwyse waarin die oogpunt en ervaringsveld van 'n jeugdige karakter sentraal staan (Ghesquiere, 1982:165; Stephens, 1992:68, 252).

Dié gebruik van die jeugdige as gesigspuntkarakter neem veral twee vorme aan, naamlik: die jong fokalisator word in die sentrum geplaas en die verteller verdwyn in die agtergrond; of die jeugdige karakter tree self as ek-verteller op. Eersgenoemde vorm skep die indruk dat die verhaal sonder ' $n$ verteller is, en dat die gebeure as 't ware deur die gesigspuntkarakter gestalte kry. Hierteenoor is die verteller in die ekvertelling prominent. Hierdie verteller kan bewustelik vertel en 'n leser 
direk aanspreek, of só vertel dat dit voorkom of hy of sy nie werklik van die vertelaksie bewus is nie.

Alhoewel die vertelinstansie veral ' $n$ invloed het op die manier waarop karakters voorgestel word, word die keuse en toerusting van karakters ook hierdeur geraak. Die wyse waarop die karakter fokaliseer en vertel (hetsy as ek-verteller of as fokalisator), is karakteropenbarend. Die karakter word sodoende direk en indirek voorgestel. Hierdie vertelwyse bring ook mee dat die sentrale karakter moeilik van buite beskryf kan word - die skrywer moet dus ander tegnieke vind waardeur dié inligting aan die leser verskaf kan word. Dieselfde geld vir die uitbeelding van die sentrale karakter se karakterontwikkeling.

Die keuse van die gesigspuntkarakter is baie belangrik aangesien die leser dié karakter se ervaringe en siening meemaak. Die leser is geneig om met hierdie karakter te simpatiseer en te identifiseer, en om sy of haar beskouing van ander karakters te deel. 'n Jeugdige karakter se siening is egter, as gevolg van die beperktheid van sy of haar kennis en insig, beperk en subjektief. Die leser deel dus in dié subjektiwiteit. 'n Gesigspuntkarakter kan ook nie weet wat ander karakters dink of voel nie. Om dié inligting te verskaf moet dit uit die dialoog en handeling blyk. Hierdie beelding verwag egter van die leser om aktief mee te werk en self gevolgtrekkings oor menslike gedrag te maak.

Die gekose vertelinstansie bepaal in 'n hoë mate hoe karakters voorgestel kan word. Indien toegang tot verskeie karakters nodig is, moet die skrywer ' $n$ ander vertelstandpunt kies as wanneer primêr op 'n enkele karakter se ervaringe gefokus word. Afwisseling tussen verskillende vertellers en fokalisators kan die beperkinge van slegs een gesigspuntkarakter oorbrug, maar identifisering en meelewing met een karakter verminder. Die skrywer moet dus die effek wat met ' $n$ verhaal bereik wil word, in ag neem wanneer oor die vertelwyse besluit word.

\section{Lewens- en werklikheidsbeskouing}

Die skrywer (en leser) leef binne 'n bepaalde tydsgewrig, samelewing en gemeenskap. Die produk (teks) wat gelewer word, word binne dié konteks geskep, ontvang en geïnterpreteer. 'n Teks is dus die resultaat van sowel die konteks waarin 'n skrywer werk, as die doelbewuste besluite wat ' $n$ skrywer neem en in die teks ten uitvoer bring.

Die aard van die kinder- of jeugboek is nóu verweef met die beskouing van die jeugdige. Dit het tot gevolg dat heelwat inhoudelike eise aan dié genres gestel word. Hierdie eise kan implisiete gemeenskapsverwagtinge wees, of eksplisiet gestel word. Onderliggend hieraan is die 
veronderstelling dat lesers (in dié geval die kind) wel deur sy leesstof beïnvloed en gevorm word. Aangesien karakters die idee van 'n storie vergestalt, speel die verwagtinge van die gemeenskap en die wêreldbeskouing van die skrywer 'n belangrike rol in die keuse, toerusting en voorstelling van karakters. Openbare reaksie op literatuur kan gewoonlik daaraan toegeskryf word dat die algemeen-geldende verwagtingsnorme deurbreek word en die geïdealiseerde beeld van die kind aangetas word. Vergelyk die aanvanklike polemiek oor boeke soos 'n Pot vol winter (Maretha Maartens) en Slinger-slinger (Francois Bloemhof). Indien 'n skrywer se werk baie van gemeenskapsverwagtinge verskil, kan dit tot gevolg hê dat die boek nie vir publikasie aanvaar, versprei, voorgeskryf, geresenseer of deur biblioteke aangekoop word nie. Boeke kan selfs verban word.

Dié eise hou dikwels verband met politiese, sosiale of kulturele verwagtinge. Groter sosiale bewustheid en verdraagsaamheid kan byvoorbeeld tot die sogenaamde kultureel-neutrale boeke aanleiding gee waarin karakters van verskillende kulturele groeperings slegs deur naamgewing aangedui word. Toenemende sensitiwiteit ten opsigte van stereotipes wat bepaalde groeperinge aanstoot gee, kan vir die skrywer van jeugboeke 'n probleem skep. Die skrywer vind dit, aldus Tucker (1981:204), toenemend moeilik om 'n skurkfiguur te skep en te blameer. Karaktertipes vorm egter deel van die lesersverwagting en die herkenning van die karakter, en bied vir die leser riglyne wat help met die ontrafeling van ' $n$ verhaal. Die jonger kind beskik nie noodwendig oor die vermoë om nuanses of teenstrydighede in persoonlikhede te begryp nie, en verkies dikwels 'n ongenuanseerde stereotiepe karakter wat nie slegs sy rol vertolk nie, maar ook na die uiterlike in dié rol pas.

Die skrywer se siening van die bedoelde lesers beïnvloed die keuse van genre, onderwerp en vormgewing (Ghesquiere, 1982:91). Die keuse van karakter, eienskappe waarmee hy of sy toegerus word, wyse van voorstelling en rol in die verhaalgebeure, gee alreeds blyke hiervan. Die skrywer kan onbewus wees van die resultaat van die keuses. 'n Skrywer kan egter ook doelbewus kies om 'n bepaalde werklikheidsbeskouing of abstrakte lewensinsig in die teks oor te dra. Dié visie word dikwels vergestalt in karakters, wat as draers van die waardes in die verhaal beskou kan word (Van der Westhuizen, 1997:82). 'n Skrywer kan byvoorbeeld 'n onsimpatieke karakter toerus met waardes wat afgekeur moet word, en die protagonis met positiewer waardes verbind. Op dié wyse word die leser beïnvloed om hom met die regte karakter te vereenselwig en só onbewustelik aan die betekenisgewing deel te hê.

Die skrywer van kinder- en jeugverhale word met verskillende verwagtinge ten opsigte van die werk gekonfronteer. Begrip van die 
verweefdheid van ideologie met die literatuur sal van waarde wees om 'n eie benaderingswyse te formuleer en keuses te kan uitoefen.

\section{Karaktervorming}

Die teikengroep, teikenleser, lewens- en wêreldbeskouing, genres en genrekonvensies, invloed van die vertelstandpunt en behoefte aan identifisering is almal aspekte wat 'n rol sal speel of in gedagte gehou behoort te word in die proses van karaktervorming.

Karaktervorming word gebruik as oorkoepelende term vir die kreatiewe proses ten opsigte van die dáárstelling van karakters. Dit behels die keuse, skep en voorstelling van karakters. Binne die fases van die skryfproses - impetus, rowwe beplanning, skryf, redigering en publikasie - vorm die keuse en skep van karakters deel van die beplanningsfase en die voorstelling van karakters deel van die skryffase.

Tydens die beplanningsfase moet daar eerstens besluit word oor die keuse van karakter; daarna word die karakter gevestig en toegerus vir sy rol. Die skrywer moet met ander woorde oordeel watter karakters nodig is vir die storie wat hy wil vertel en oor watter eienskappe hulle moet beskik, en beplan die karakter hiervolgens. Dié fase kan in verband gebring word met die storie of geskiedenis van die verhaalwêrelde.

Tydens die skryffase kom die karakter fisies tot stand. Die skrywer is nou besig met die vertelproses en die konkrete daarstelling van die verhaal. $\mathrm{Hy}$ of sy kies die vertelinstansie, inligtingsbronne en tegnieke wat die waarskynlikste tot 'n bepaalde of beoogde leesresultaat sal lei, en stel die karakter aan die hand hiervan in die teks voor.

Tydens die redigeringsfase van 'n manuskrip bepaal die skrywer of in die bedoelinge geslaag is. Indien die teks nie aan die verwagtinge voldoen nie, moet die redes daarvoor vasgestel word. Die aangewese manier is om die eerste vlak waar 'n probleem kon ontstaan te identifiseer en hiervandaan verder te werk (Knight, 1997:56). Aangesien die verskillende boublokke van 'n verhaal ineenskakel, sal veranderinge aan een aspek die geheel beïnvloed. Karakters kan dus nie in isolasie gehanteer word nie, en besluite wat met redigering oor karakters geneem word, sal meebring dat die skrywer ook elders wysigings (moet) aanbring. Die sukses van 'n verhaal hang egter in 'n hoë mate af van effektiewe karakterbeelding. Die keuse van 'n gesigspuntkarakter is veral belangrik.

\subsection{Keuse van karakters}

Die keuse van karakters hang af van die betrokke verhaal, die rol en funksie van die karakters in die verhaal, en die implisiete leser. Karakters 
vervul verskeie funksies in 'n verhaal. Sommige karakters vorm die kern van die storie en stu die gebeure vorentoe, terwyl ander bygevoeg word ter wille van kontras, spanning, brandstof vir die verhaal, om inligting te verskaf, ensovoorts. 'n Speurverhaal benodig by implikasie 'n speurder sy dit dan ook net ' $n$ nuuskierige kind. Ter wille van spanning benodig ' $n$ verhaal moontlik opponerende karakters. Die onderlinge balans tussen karakters (soort, eienskappe, aantal) word deur die betrokke verhaal bepaal. Benewens die tema en inhoud, oefen ook die lengte en omvang van 'n verhaal 'n invloed op die keuse van karakters uit.

Die leser wat die skrywer in gedagte het, rig veral die keuse van die hoofkarakter. In kinder- en jeugverhale is daar ' $n$ aantoonbare verband tussen die ouderdom van die karakters en dié van die bedoelde leser. Jong lesers verkies karakters wat 'n jaar of twee/drie ouer as hulself is, maar steeds jonk genoeg is om soortgelyke ervarings te kan deel. Subgenres word egter gekenmerk deur eiesoortige konvensies wat ook volwassenes as hoofkarakters kan insluit.

\subsection{Skep van karakters}

In dié fase word die betrokke karakter uitgedink en met eienskappe toegerus. Verskeie metodes van karakterskepping kan onderskei word, waaronder die biografiese en outobiografiese metodes. Laasgenoemde behels dat die skrywer die self in die fiksionele karakter projekteer (Novakovich, 1995:51-54). In die geval van 'n jeugdige (hoof)karakter bring dit mee dat die skrywer weer soos 'n kind of tiener moet voel en dink.

Karaktertoerusting behels méér as die blote toekenning van persoonskenmerke of eienskappe, maar is deel van ' $n$ dinamiese, organiese proses waartydens die karakter met inagneming van die verhaal as geheel toegerus word. Verskillende vlakke of dimensies van karaktereienskappe of -inligting kan onderskei word. Dit kom daarop neer dat 'n karakter eers omlyn en daarna verfyn word, of anders gestel, eers gevestig en daarna toegerus word. Die vlakke wat hiervolgens onderskei kan word, is kern-, kenmerkende en uitgebreide besonderhede (Greyling, 1999:132).

Kernbesonderhede behels die basiese kenmerke van 'n karakter (geslag, ouderdom, beroep, aard) en sluit nóu aan by die keuse van die karakter. Deur die toekenning van kenmerkende besonderhede word karakters van mekaar onderskei en verder vir hul rol in die verhaal toegerus. Hierdie besonderhede sluit aspekte in soos naamgewing, voorkoms, spraakpatroon, maniërismes, vermoëns en vaardighede. Uitgebreide besonderhede individualiseer en nuanseer die karakter. Die 
aard van die uitgebreide besonderhede hang af van die betrokke karakter en verhaal en behels onder andere die karakter se verlede, motivering, houding, verhouding met ander karakters en karaktergroei en -ontwikkeling.

Die aard en omvang van karakterinligting word onder meer bepaal deur die rol in die verhaal (sentrale karakters moet volledig toegerus word); die funksie in die verhaal (opponerende karakters moet met botsende behoeftes en doelwitte toegerus word); die effek wat met 'n bepaalde karakter bereik moet word (identifisering met, liefhê, vrees); die betrokke tekstipe, ensovoorts. Die skrywer moet ook besluit of die karakter met stereotiepe kenmerke toegerus word, en of bestaande rolpatrone en verwagtinge deurbreek word.

Planmatige karakterskepping en -toerusting bring mee dat die skrywer doelgerig oor karakters dink. Dit kan tot duideliker en effektiewer karakters lei, en kan ook groter karakterverskeidenheid meebring. Die skrywer word ook sodoende bewus of die karakter bloot 'n nabootsing van soortgelyke karakters is (stereotipe) en of dit 'n oorspronklike skepping is.

\subsection{Voorstelling van karakters}

Die voorstelling van karakters behels dat die uitgedinkte karakter in die teks gestalte kry. Dit is veral die keuse van vertelinstansie, die verhouding tussen beelding en vertelling, en die tegnieke van karakterisering wat van belang is - en wat die skrywer na gelang van behoefte sal afwissel en kan manipuleer.

Die keuse en aanwending van die vertelstandpunt beïnvloed die afstand tussen die implisiete skrywer en leser - en daarmee saam die wyse en omvang waarmee karakter voorgestel word en deur die leser geïnterpreteer kan word.

Die gebruik van 'n jeugdige gesigspuntkarakter bring byvoorbeeld mee dat die skrywer en leser dié beperkte visie van die karakter deel. Die gevolg hiervan kan wees dat ander karakters vaag of baie subjektief voorgestel word. Vir balans kan dit nodig wees dat die skrywer tegnieke moet bedink om karakters voor te stel - byvoorbeeld deur direkte beelding deur middel van handeling en spraak.

Die leser en leesresultaat wat die skrywer in gedagte het, sal ook bepaal hoe die karakters voorgestel word. Karakters wat konkreet voorgestel en goed gevestig is, bring mee dat die jong leser makliker ' $n$ beeld van die karakter kan vorm. In eietydse realistiese fiksie kan 'n vaer karakter egter weer by die leser die idee skep dat hy of sy soortgelyke karakters ken, 
en kan hy of sy deur projeksie geredelik met dié vae karakter identifiseer (Nodelman, 1981:177-183).

Die skrywer het verskeie karakteriseringstegnieke beskikbaar, byvoorbeeld naamgewing, blokkarakterisering, uiterlike voorkoms, handeling en spraak. 'n Karakter word gewoonlik deur 'n kombinasie van tegnieke voorgestel. Die aard en fokus van 'n verhaal bepaal watter tegnieke die geskikste is. Avontuurverhale beklemtoon gewoonlik karakters se uiterlike handeling, vaardighede en voorkoms. In verhale waar karakterontwikkeling sentraal staan, word eerder gebruik gemaak van tegnieke wat toegang tot die karakter se gedagte en gevoelslewe bied, soos innerlike monoloog en bewussynstroomtegnieke.

Deur middel van herhaling, vergelyking, kontrastering en akkumulasie word die aanvanklike beeld wat van die karakter gevestig is, versterk en uitgebou. Die verskeidenheid, kombinasie en aanwending van tegnieke dra by tot die beeld wat die leser van ' $n$ karakter opbou. Die effektiewe gebruik van dié tegnieke kan daartoe bydra dat die leser 'n goeie voorstelling van die karakter kan maak, en só ook 'n verhaal makliker volg en die gebeure meeleef.

Jong lesers is in 'n hoë mate aan die konkrete en aan uiterlike gebeure en handeling gebonde. 'n Groter bewustheid van menslike emosies, beweegredes en verhoudinge lei daartoe dat ouer lesers in karakternuanses en innerlike handeling geïnteresseerd kan raak. 'n Vaardige skrywer kan albei tipes lesers in dieselfde werk bereik.

\section{Slotbeskouing}

Die skrywer kan 'n verhaal en karakters op so 'n manier aanbied dat dit vir ' $n$ bepaalde teikengroep toeganklik is. Die teikengroep kan omvangryk wees of kan spesifiek afgebaken word. Die aspekte wat in die artikel belig is, is van belang ten opsigte van die keuse, skep en voorstelling van karakters in verhale vir 11-14-jariges. Hierdie beginsels kan egter ook op literatuur vir jonger of ouer lesers van toepassing gemaak word. Hierbenewens is daar ook algemene aspekte ten opsigte van karakters en karakterbeelding wat nie in dié artikel gehanteer is nie, maar wat ook belangrik is vir die effektiewe keuse, skep en voorstelling van karakters.

'n Vaardige skrywer kan wel 'n verhaal, en die karakters daarin, vir die leser wat hy in gedagte het, toeganklik maak. 


\section{Bibliografie}

Applebee, A.N. 1978. The child's concept of story: Ages two to seventeen. Chicago, IL : University of Chicago Press.

Aucamp, H. 1992. Windperd: Opstelle oor kreatiewe skryfwerk. Pretoria : HAUMLiterêr.

Barenboim, C. 1981. The development of person perception in childhood and adolescence: From behavioural comparisons to psychological constructs to psychological comparisons. Child Development, 5:129-144.

Beach, R. 1985. Discourse conventions and researching response to literary dialogue. In: Cooper, C.R. (ed.) Researching response to literature and the teaching of literature: Points of departure. Norwood, NJ : Ablex. p. 103-127.

Beach, R. \& Wendler, L. 1987. Developmental differences in response to a story. Research in the Teaching of English, 21(3):286-298, Oct.

Card, O.S. 1988. Characters and viewpoint. Cincinnati, OH: Writer's Digest Books

Dillon, G.L. 1982. Styles of reading. Poetics Today, 3(2):77-88.

Ghesquiere, R. 1982. Het verschijnsel jeugditeratuur. Leuven : Acco.

Greyling, S.F. 1999. Die keuse, skep en voorstelling van karakters in verhale vir 1114-jariges. Potchefstroom: PU vir CHO. (Ph.D.-proefskrif.)

Hill, J.P. \& Palmquist, W.J. 1978. Social cognition and social relations in early adolescence. International Journal of Behavioral Development, 1:1-36, Jan.

Jauss, H.R. 1977. Ästhetische Erfahrung und literarische Hermeneutik 1. München Wilhelm Fink.

Knight, D. 1997. Creating short fiction: the classic guide to writing short fiction. New York, NY : Steenberg Martin's Griffen.

Lohann, C.A. 1972. Die bekroonde kinderboek en die aanvaarding daarvan deur die kind, met spesiale verwysing na Suid-Afrika. Potchefstroom : PU vir CHO. (D.Phil. (Bibl)- proefskrif.)

Nodelman, P. 1981. How typical children read typical books. Children's Literature in Education, 12(4): 177-185.

Novakovich, J. 1995. Fiction writers's workshop. Cincinnati, OH : Story Press

Protherough, R. 1983. Developing response to fiction. Milton Keynes: Open University Press.

Shaffer, D.R. 1988. Social and personality development. (2nd ed.) Pacific Grove, CA : Brooks/Cole Publishing Company.

Steenberg, D.H. 1992. Die opbou van 'n leser. In: Du Plessis, H. \& Steenberg, D. (reds.) Skryfateljee: Gesprekke oor skryfwerk. Pretoria : Van Schaik. p. 143151.

Steenberg, D.H. 1991. Moontlikhede vir die storieverteller. Tydskrif vir Letterkunde, XXIX(2):31-44, Mei.

Steenberg, E. 1986. Is kinderliteratuur 'n selfstandige literêre genre? Tydskrif vir Letterkunde, XXIV(2):85-88, Mei.

Steenberg, E. 1987. Fantasie en die kinderboek. Pretoria : HAUM-Literêr.

Stephens, J. 1992. Language and ideology in children's fiction. London : Longman.

Tucker, N. 1981. The child and the book: A psychological and literary exploration. Cambridge : Cambridge University Press.

Van der Westhuizen, E.S. 1997. Die representasie van die visie in die verhalende prosa van Elsabe Steenberg. Potchefstroom : PU vir CHO. (Ph.D.- proefskrif.)

Vos, J. \& Meijer, C. 1985. Wegwijs in de jeugditeratuur. Leiden : Nijhoff.

Wadsworth, B.J. 1989. Piaget's theory of cognitive and affective development. (4th ed.) New York, NY : Longman. 
Whitehead, F., Capey, A.C. Maddren, W. \& Wellings, A. 1978. Children and their books. Hampshire : Macmillan Education. (Schools Council Research Studies.)

\section{Kernbegrippe:}

genrekonvensies

karakterisering

jeugliteratuur

jeugverhale

skep van karakters

skryfkuns

\section{Key concepts:}

characterisation

creating characters

creative writing

genre conventions

youth literature 
